\title{
STRUCTURAL GEOLOGY OF CENTRAL PEARY LAND, NORTH GREENLAND
}

\author{
Stig A. Schack Pedersen
}

\section{Introduction}

The region investigated in 1978 between Jørgen Brønlund Fjord - Øvre Midsommersø in the south and Frederick E. Hyde Fjord in the north consists of $c .1 \frac{1}{1 / 2} \mathrm{~km}$ thickness of Lower Palaeozoic carbonates overlain by an up to $1 \mathrm{~km}$ thick series of Silurian flysch (Christie \& Peel, 1977). In general the region is part of the Palaeozoic platform that can be divided into three major E-W trending physiographic belts: a southern belt where the carbonates form plateaus incised by steep valleys, a central belt consisting of characteristic conical mountains marked by concentric terraces of resistant sandstone beds in the flysch (Dawes, 1976, fig. 249 ), and in the fold belt to the north the mountains rise up to altitudes of $1000-1500 \mathrm{~m}$ and are covered by extensive ice caps (fig. 17).

The southern border of the region, the Øvre Midsommersø - Jørgen Brønlund Fjord area, was mapped by Jepsen (1971) while the Lower Palaeozoic stratigraphy in the central part of the region has been established by Christie \& Peel (1977) at Børglum Elv. Some structural aspects of the geology at Frederick E. Hyde Fjord are briefly described by Dawes (1971) and Dawes \& Soper (1973).

Prior to the field work a comprehensive photogeological interpretation was carried out on vertical aerial photographs (scale c. 1:60000) and compiled on six uncontoured 1:100000 photomosaic maps. The 1978 field work and laboratory studies using a Kern PG 2 photogrammetric instrument form the first detailed study of the fold belt margin. For descriptive purposes the region investigated in 1978 has been subdivided into seven areas (fig. 17), the main structural features of which form the basis of this report.

\section{Areal divisions}

\section{Carbonate platform, area 1}

The carbonate platform consists of alternating dolomite and calcite limestone formations ranging from Lower Cambrian to Lower Silurian in age (Christie \& Peel, 1977). Two characteristic marker horizons have been useful in the photogeological interpretation. In the southern part of the platform the black, middle member of the Ordovician Wandel Valley Formation can be followed c. $40 \mathrm{~km}$ to the east and $60 \mathrm{~km}$ to the west of Børglum Elv. In the northern part of the area the dark banded upper member of the un-named Silurian dolomite formation can be recognised c. $80 \mathrm{~km}$ to the east and c. $70 \mathrm{~km}$ to the west of Børglum Elv. 


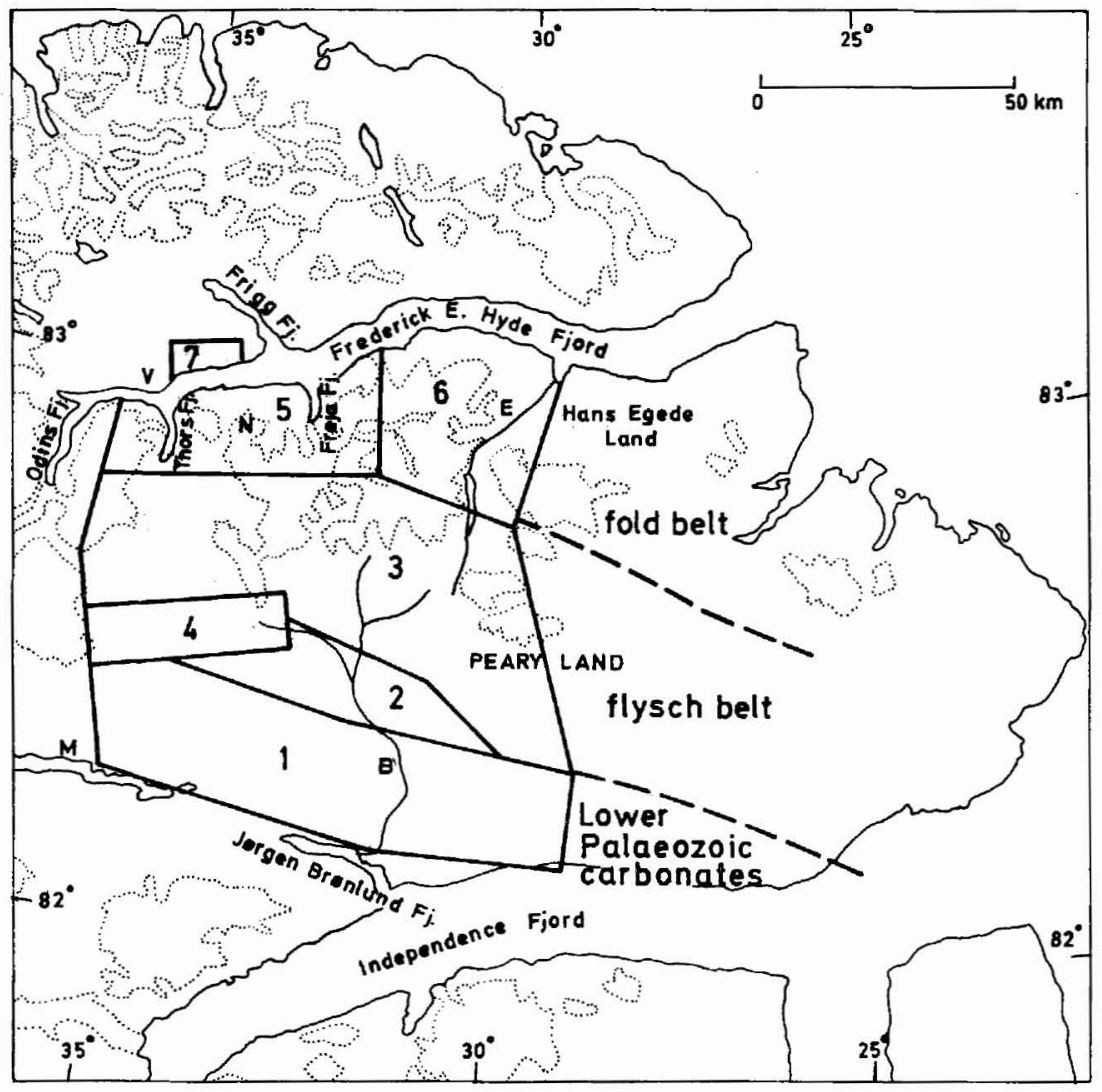

Fig. 17. Location map, central Peary land, showing division into areas described in the text. B Børglum Elv, E Esrum Elv, M Øvre Midsommersø, N Nordkronen, V Vølvedal.

The beds are subhorizontal with a slight inclination $\left(1^{\circ}-2^{\circ}\right)$ to the north and displaced along ENE-trending vertical faults as may be seen notably in the central part of this area at Børglum Elv. The maximum vertical separation recorded is $150 \mathrm{~m}$ with the southern block downthrown. The faults can only be traced a few kilometres (up to $7 \mathrm{~km}$ ) along the strike before they fade out, and therefore they are regarded as hinge faults.

\section{Saddle and dome structures in the northern part of the carbonate platform, area 2}

Area 2 is characterised by saddle and dome structures. From the photogeological interpretation the sizes of the domes were estimated at 1-3 km in diameter, but their shape and distribution are irregular. The axes of the saddle synclines trend NW-SE and WSW-ENE. The maximum dip of the beds is up to $30^{\circ}$, but dips between $8^{\circ}$ and $15^{\circ}$ prevail. 
In the western part of the area the saddle syncline axes steepen due to a monoclinal flexure along the southern border of area 4 .

The saddle and dome structures may be related to interference patterns between weak folding and faulting. Similar structures are also referred to as dome and basin structures and are common in foreland areas of fold belts (Less, 1952).

\section{Flysch belt, area 3}

The strata in this area are generally flat-lying and undeformed. Saddle and dome structures have been observed at Børglum Elv in the southern part of the area. A fault system trending E-W can be traced from area 4 c. $50 \mathrm{~km}$ to the east where it dies out near Esrum Elv.

In vertical cliff sections the beds form rectangular columns due to a very strongly developed conjugate joint system striking NNE and ESE.

\section{Syncline - graben structure, area 4}

In the western part of the platform the southern border of the Silurian flysch follows a broad synclinal structure $c$. $5 \mathrm{~km}$ wide with an axis trending WSW-ENE. The syncline shows slight asymmetry with dips up to $45^{\circ}$ on the southern limb and a more steeply dipping northern limb with dips up to $70^{\circ}$. Two major fracture zones run parallel to the limbs on each side of the syncline. Here the Silurian limestone is broken up by a complex network of joint systems and fault/breccia zones in which rhomb-shaped clasts $(1 \times 5 \mathrm{~m}$ in size $)$ are common.

Stereogram plots of poles to bedding planes form a diffuse great circle or large small circle pattern interpreted as reflecting a conical surface with its apex to the east. The syncline graben structure was therefore probably produced by subsidence of a deep-seated block bordered by a ENE-trending fault to the south and a more E-W trending fault to the north.

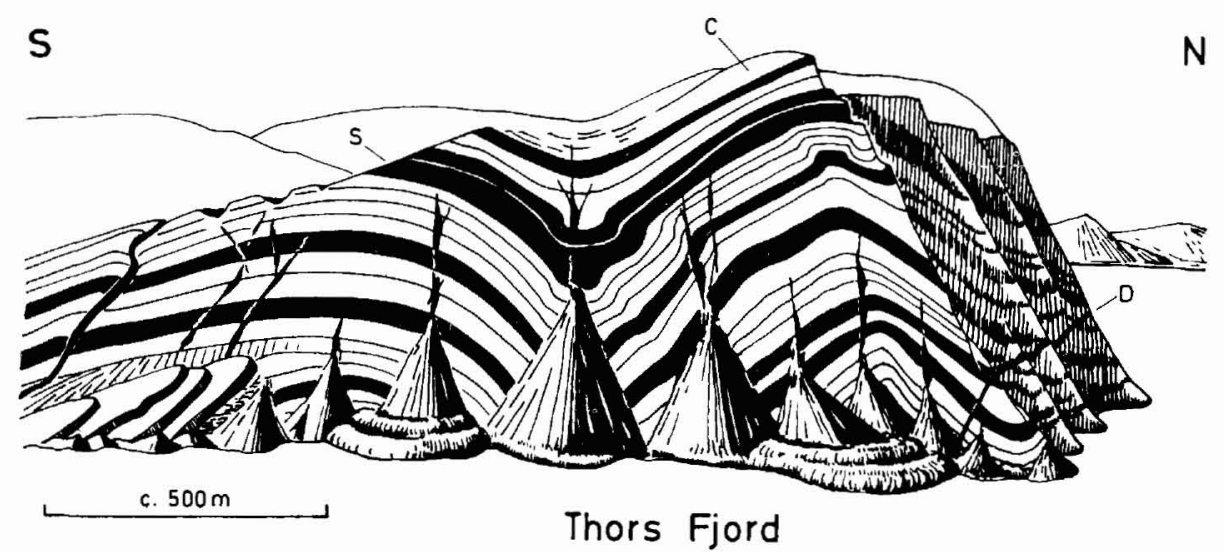

Fig. 18. Profile of west side of Thors Fjord. The folded rocks belong to the un-named Silurian flysch formation. S shale rich beds, C conglomerate, D dyke (E-W trending and presumably of Cretaceous-Tertiary age). 
S

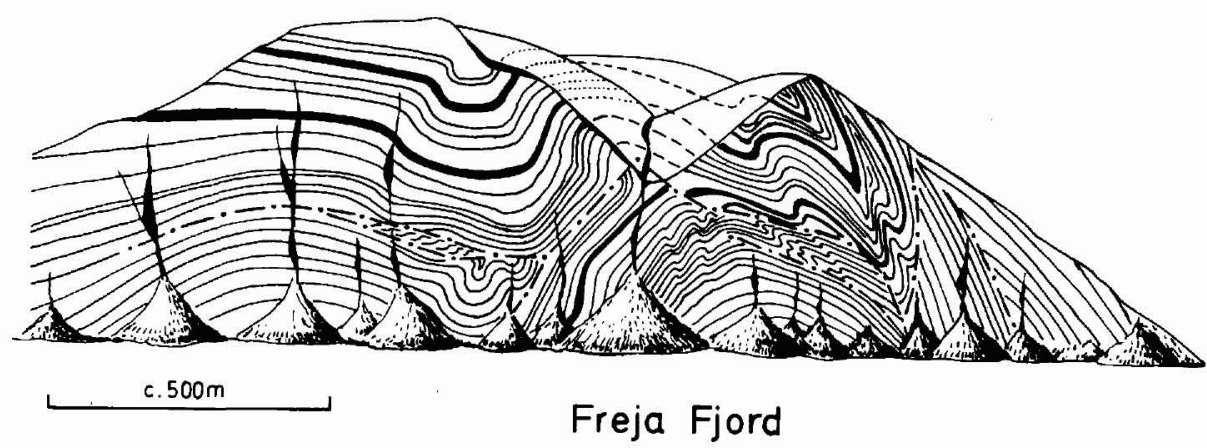

Fig: 19. Profile of west side of Freja Fjord. Folds in the Silurian flysch are overturned to the south; thrust faults and bedding plane slides create a complex deformation pattern.

\section{Fold belt between Thors Fjord and Freja Fjord, area 5}

The southernmost gentle folds of the North Greenland fold belt appear in the northern part of the flysch zone c. $15 \mathrm{~km}$ south of Frederick E. Hyde Fjord. The folds have a southerly vergence, and the fold axes trend $\mathrm{E}-\mathrm{W}$, roughly parallel to the fjord. To the north $c$. $5 \mathrm{~km}$ south of Frederick E. Hyde Fjord the folds develop into close folds well seen in the beautifully exposed profile at Thors Fjord and Freja Fjord (figs. 18 \& 19). Here the folds have amplitudes of $500 \mathrm{~m}$ and wave lenghts of $c .2 \mathrm{~km}$.

In the northernmost part of the area between Thors Fjord and Freja Fjord the folds are overturned to the south. The Silurian flysch interbedded with olistostrome limestone conglomerates has been overthrust by older rock units including graptolite shale of (?) Lower Ordovician age. Fig. 20 is a map of part of the area between Thors Fjord and Freja Fjord, and structural orientations are presented on the stereograms of fig. 21 . Note that the thrust planes have been folded on an axis (fig. 21B) coinciding with the general fold axis of the area (fig. 21A). Hence it is concluded that the trust movements predate the folding, and slickenside lineations (fig. 21B) indicate the thrust movement is to the south.

A number of joint systems have been measured in the area. In the southern part a conjugate ENE and SSE to S striking system dominates. This system, which is also known farther south, is responsible for a remarkable columnar outcrop of the conglomerate at the top of Nordkronen. The beds of the highest mountain (Wistars Bjerg) of Nordkronen dip $30^{\circ} \mathrm{N}$ due to folding with E-W trending axes, and the joint system is regarded as later than the folding.

In the steeply dipping beds at Thors Fjord a conjugate system is seen to have participated in the folding. A reorientation of this system to its pre-folding position suggests correspondence to conjugate joint system in the flat-lying beds at camp 9 (fig. 20). It may thus be inferred that the joint system, striking $\mathrm{NE}$ and $\mathrm{SE}$, represents an earlier tectonic phase than the folding. 


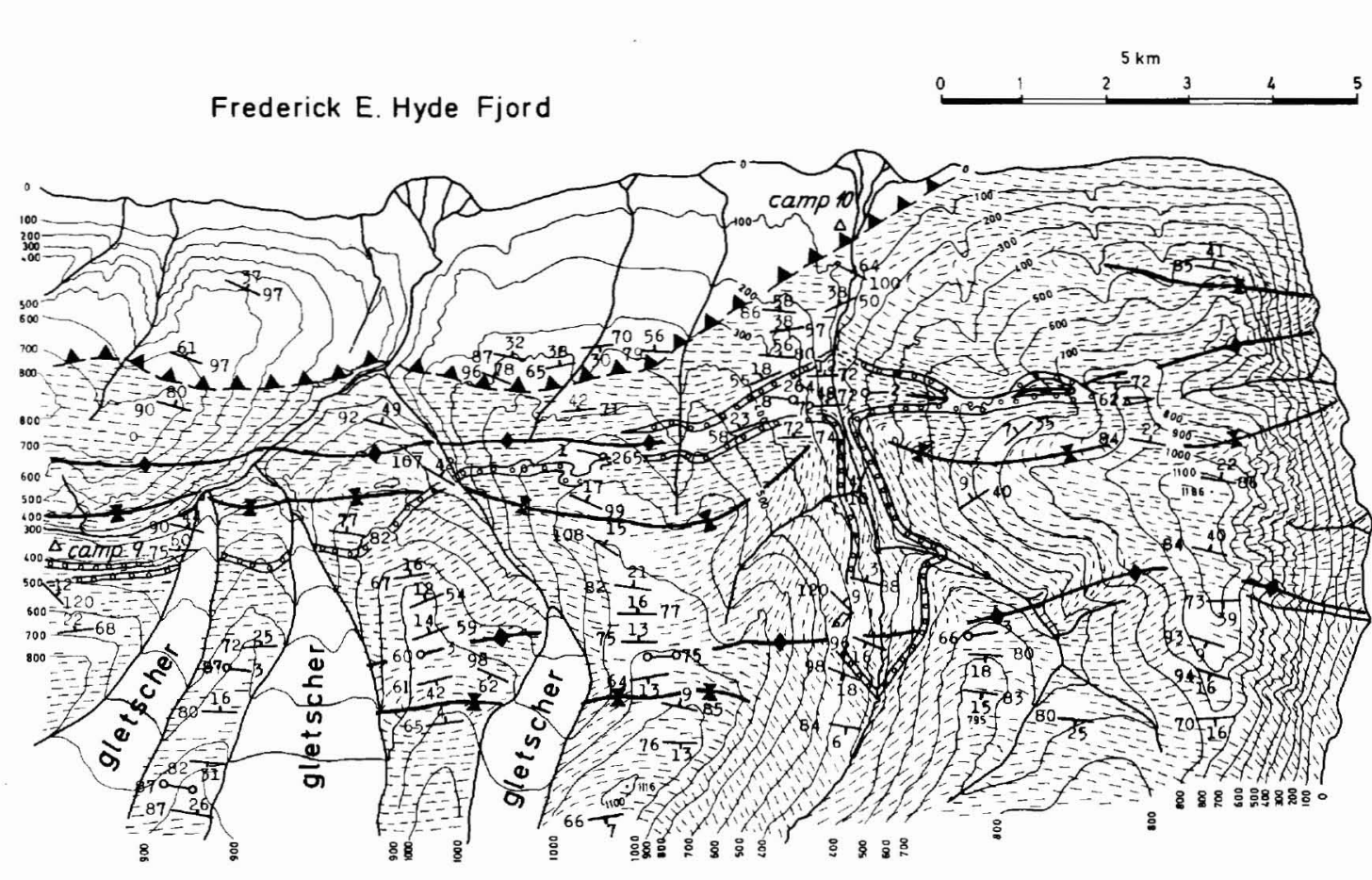

Fig. 20. Geological map of the area around Freja Fjord with the position of camps 9 and 10 shown. Topography and geological boundaries were drawn out on a Kern PG 2 photogrammetric instrument, and the majority of the structural directions were measured photogrammetrically.
THRUST UNIT WITH LOWER ORDOVICIAN SHALE

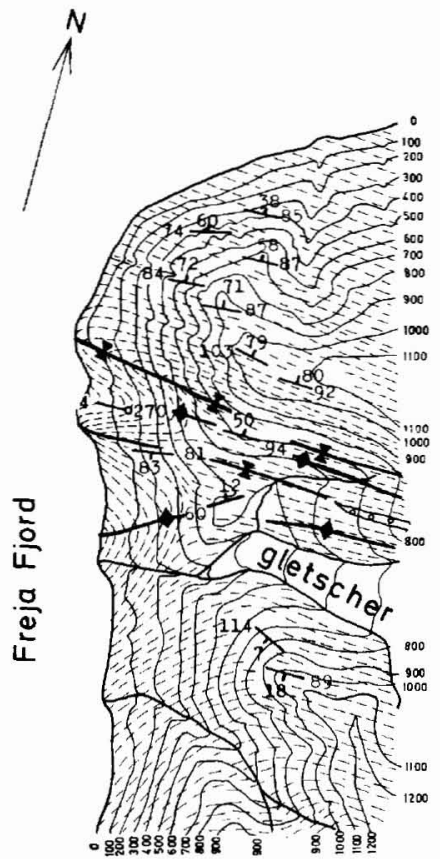

79 S6 STRIKE AND DIP, NUMRERS IN DEGREES

$720-2$ FOLD AXIS, NUMBERS IN DEGREES

LIMESTONE CONGLOMERATE 
60
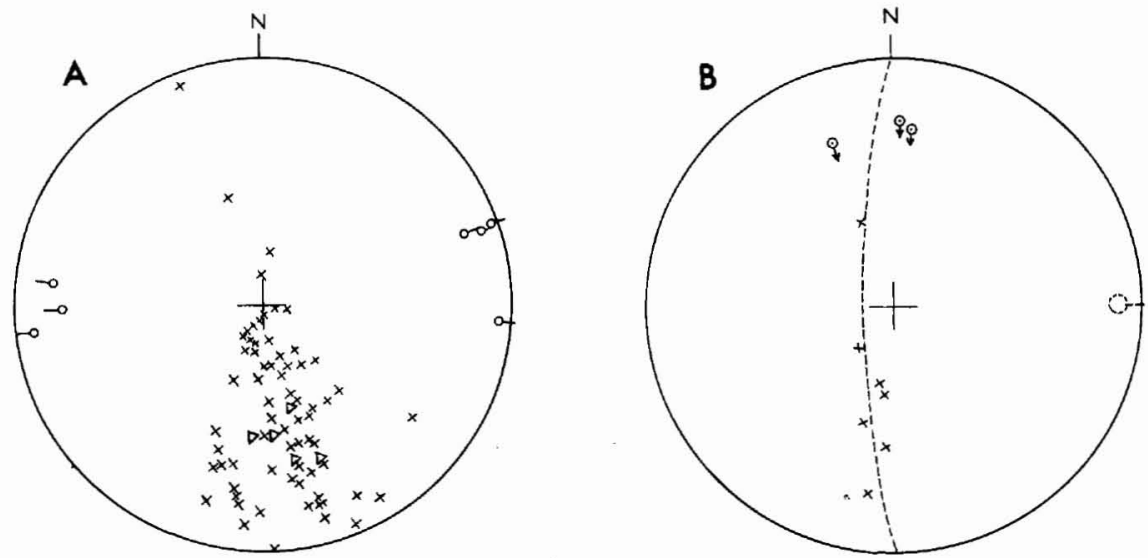

$$
\begin{aligned}
& \times \text { strike/dip, pole to bedding plane } \\
& \text { a fold axis, measured } \\
& \Delta \quad \text { pole to axial plane }
\end{aligned}
$$

$\times$ pole to thrust plane

$\rightarrow$ slickenside lineation

Fig. 21. Stereograms from the area of camps 9 and 10, equal area projection, lower hemisphere. A: bedding, fold axes and axial planes, field measurements. B: thrust planes and slickenside lineations, field measurements. Arrow on slickenside lineation indicates direction of movement of overlying block. $\pi$ circle and $\pi$ axis are shown spaced.

\section{Fold belt in the north-west part of Hans Egede Land area 6}

East of Freja Fjord the general fold axes swing to the SE, as illustrated by measurements from an area in the north-western part of Hans Egede Land (fig. 17). The folds are inclined to the south, and the constructed fold axis shown on the stereogram fig. 22 indicates a plunge to the SE $\left(118^{\circ}\right)$ at $10^{\circ}$. The shapes of the folds are much the same as farther west (fig. 18), but the deformation has been more penetrative resulting in the development of a distinct slaty cleavage in the shaly beds of the Silurian flysch. It is not possible to define the exact orientation of the axial plane for the folds, and the variable orientation of the cleavage (fig. $22)$ shows that it is fanning. The zone axis of the cleavage is oblique to the fold axis $\left(c .20^{\circ}\right.$, fig. 22). This deviation is explained as follows. The $\mathrm{E}-\mathrm{W}$ trending folds were formed in an early stage due to $\mathrm{N}-\mathrm{S}$ compresssion. In the eastern areas these folds have later been superimposed by a NE-SW compressive deformation resulting in a bending of the E-W trending axes to the south-east and the development of the slaty cleavage perpendicular to the stress direction but with an oblique low angle to the earlier formed folds. The problem has most recently been discussed by Borradaile (1978).

At the northernmost end of Esrum Elv the fine-grained rocks of the Silurian flysch can be described as slates and a silky sheen typical for phyllites may be seen.

\section{Thrust separated rocks north of Frederick E. Hyde Fjord area 7}

Between Frigg Fjord and Vølvedal southward verging overthrust folds and thrusts are seen in the steep profile on the north side of Frederick E. Hyde Fjord. A preliminary 


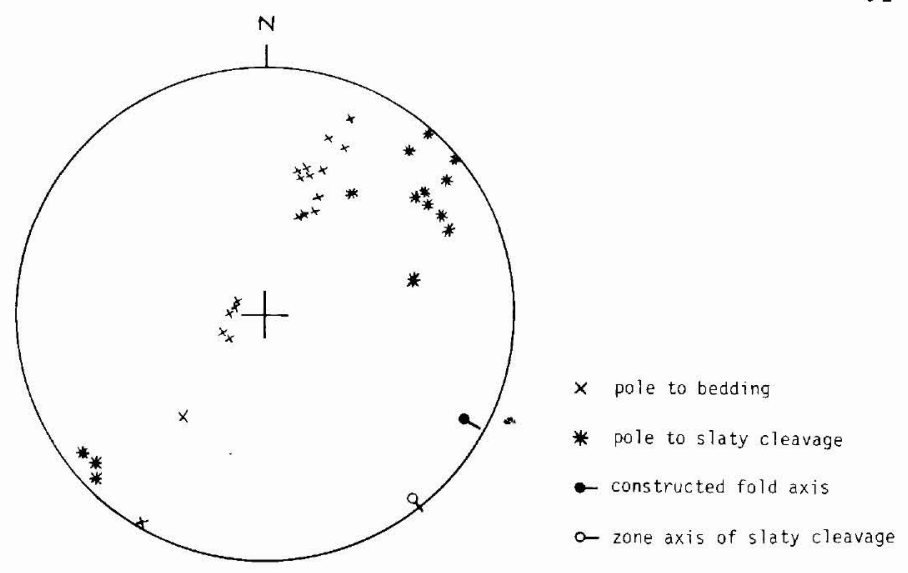

Fig. 22. Stereogram from area 6, equal area projection, lower hemisphere.

reconnaissance distinguished three major lithological units, shales, turbidites and conglomerates. The lowermost unit consists of yellow-red weathering green shales and siltstones overlain by black shales interbedded with chert and thin limestone beds. The overlying turbidites are extensive and comparable to the Silurian flysch to the south. A light grey polymict conglomerate grading upwards into quartzitic sandstones constitutes the uppermost unit Farther to the south-west this unit is replaced by a limestone conglomerate-calcarenite unit.

Three thrust surfaces have been recognised, and the average thickness of the thrusted sheets is $300 \mathrm{~m}$. The maximum separation is estimated to be more than $2 \mathrm{~km}$ in the westernmost thrust, while the displacement has been measured to $1 \mathrm{~km}$ in the easternmost thrust. The thrusts have been affected by later folding resulting in steep dips to the north-north-east.

The constructed fold axis trends SE $\left(120^{\circ}\right)$ and the beds dip $c .40^{\circ} \mathrm{NE}$. This axis direction coincides with the general fold axis of area 6 , and the deformation seen in these areas is probably caused by the same tectonic event. This deformation phase predates the E-W trending basic dykes north and south of Frederick E. Hyde Fjord, which are of Cretaceous-Tertiary age (Dawes, 1971).

\section{Discussion}

The fold belt area here described corresponds to the central part of tectonic-metamorphic zone 2 of Dawes \& Soper (1973, p. 127, fig. 8), who describe it as follows: "The southern margin of the folded zone is abrupt but involves no dislocation. The overall structure is characterized by large north facing fold pairs which are monoclinal in the south but, northward, develop overturned common limbs. These folds appear to be superimposed on earlier upright or south-facing folds. These two phases of essentially coaxial folding may be correlated with phases $D_{1}$ and $D_{2}$ recognized farther north".

Although Dawes and Soper noted the existence of several small-scale southward-facing folds and a few large-scale southward-facing folds at the margin of the fold belt in Peary Land, e.g. south of Frederick E. Hyde Fjord (Dawes, 1971, p. 219), they have not stressed the significance of these folds in their regional synthesis. On the contrary the author has not 
seen any structures that could be interpreted as a northerly refolding of southward-vergent folds.

Another important feature of this zone which has not previously been recognized, is a series of thrust units with southerly direction of transport. The displacement is in the order of a few kilometres and the thrusts are a notable feature in the entire area around Frederick E. Hyde Fjord.

\section{Conclusions}

A section through central Peary Land from south to north reveals increasing tectonic deformation of the sediments. The lower Palaeozoic platform in the south has only been subjected to block faulting. In the central platform area the first weak folding appears as dome and saddle structures. Farther to the north gentle folds occur with well-defined E-W crests, and towards Frederick E. Hyde Fjord the folds are overturned to the south and the rocks are displaced by north-dipping thrusts.

In the fold belt two different deformation phases may be distinguished. The older deformation is due to $\mathrm{N}-\mathrm{S}$ compression generating $\mathrm{E}-\mathrm{W}$ trending folds, and the younger deformation was controlled by NE-SW compression resulting in bending of earlier folds to the SE and development of slaty cleavage.

\section{References}

Borradaile, G. J. 1978: Transected folds: a study illustrated with examples from Canada and Scotland. Bull. geol. Soc. Amer. 89, 481-493.

Christie, R. L. \& Peel, J. S. 1977: Cambrian-Silurian stratigraphy of Børglum Elv, Peary Land, eastern North Greenland, Rapp. Grønlands geol. Unders. 82, 48 pp.

Dawes, P. R. 1971: The North Greenland fold belt and environs. Bull. geol. Soc. Denmark 20, 197-239.

Dawes, P. R. 1976: Precambrian to Tertiary of northern Greenland. In Escher, A. \& Watt, W. S. (edit.) Geology of Greenland, 248-303. Copenhagen: Geol. Surv. Greenland.

Dawes, P. R. \& Soper, N. J. 1973: Pre-Quaternary history of North Greenland. In Pitcher, M. G. (edit.) Arctic Geology. Mem. Amer. Ass. Petrol. Geol. 19, 117-134.

Jepsen, H. F. 1971: The Precambrian, Eocambrian and early Palaeozoic stratigraphy of the Jørgen Brønlund Fjord area, Peary Land, North Greenland. Bull. Grønlands geol. Unders. 96 (also Meddr Grønland 192, 2) 42 pp.

Less, G. M. 1952: Foreland folding. Quart. J. geol. Soc. Lond. 108, 1-34. 